\title{
Power and Inequality in Open Science Discourses ${ }^{1}$
}

\section{Poder e desigualdade nos discursos da Ciência Aberta}

\author{
Denisse Albornoz \\ Knowledge G.A.P, Canada \\ albornoz.denisse@gmail.com \\ Leslie Chan \\ University of Toronto Scarborough, Canada \\ chan@utsc.utoronto.ca
}

\begin{abstract}
This article seeks to address issues of power and inequality in Open Science discourses, based on the research findings of the Open and Collaborative Science in Development Network (OCSDNet), an international research network that between 2014 and 2017 studied whether, and under what conditions, open science contributed to the effective application of research towards sustainable development. The network approached Open Science from a Global South perspective and collectively produced a set of values that ought to be at the foundation of a more inclusive and equitable practice of Open Science. However it also found that these values are currently missing in the most prominent Open Science policies. This article prompts the question: what assumptions are embedded in Open Science policies - whose interests are they serving and in turn whose interests are they neglecting? With this provocation it seeks to critically question Open Science policies by offering three alternative ways to think about Open Science from the perspective of Global South grassroots communities.
\end{abstract}

Keywords: Open science. Policies. Knowledge geopolitics. Global south. Situated openness.

Resumo: O artigo procura abordar questões de poder e desigualdade nos discursos da Ciência Aberta, com base nos resultados de pesquisa da Rede de Ciência Aberta e Colaborativa em Desenvolvimento (OCSDNet), uma rede internacional de pesquisa que, entre 2014 e 2017, estudou se, e sob quais condições, a Ciência Aberta contribuiu para a aplicação efetiva de pesquisas direcionadas para o desenvolvimento sustentável. A rede abordou a Ciência Aberta desde a perspectiva do Sul Global e produziu coletivamente um conjunto de valores que deveriam estar na base de uma prática mais inclusiva e equitativa da Ciência Aberta. No entanto, o trabalho também identificou que esses valores estão atualmente ausentes nas políticas mais proeminentes da Ciência Aberta. O artigo questiona: quais assunções estão incorporadas nas políticas da Ciência Aberta - quais interesses estão servindo e, por sua vez, quais interesses estão negligenciando? Com essa provocação, procura-se questionar criticamente as políticas da Ciência Aberta, oferecendo três formas alternativas de pensar sobre ela a partir da perspectiva das comunidades de base do Sul Global.

Palavras-chave: Ciência aberta. Políticas. Geopolítica do conhecimento. Sul global. Abertura contextualizada.

${ }^{1}$ Adaptation of speaking notes for the presentation given at the Diversity, Equity and Inclusion panel of OpenCon 2017. 


\section{Introduction}

This article seeks to address issues of power and inequality in Open Science discourses, based on the research findings of the Open and Collaborative Science in Development Network (OCSDNet). Funded by IDRC of Canada and DFID in the UK, OCSDNet was an international research network that between 2014 and 2017 studied whether, and under what conditions, open science and open approaches to knowledge production contributed to the effective application of research towards sustainable development and the wellbeing of diverse local, regional and global communities.

\section{Defining Open Science from a Global South Perspective}

The first challenge for OCSDNet was to operationalize Open Science in the study. Back in 2014, the term was just starting to get traction in North America and Europe, but its potential role in academic knowledge production in the global South received relatively little attention. As a result, most of the definitions about what Open Science meant and how it should be practiced were also stemming from these regions - such as the widely cited work of Sonke Bartling, Benedikt Fecher, Sascha Friesike and Michael Nielsen. The growing Euro-American scholarship on the subject, along with the guidelines and tools promoted by organizations such as Centre for Open Science and FOSTER, operationalized Open Science as a set of technical tools and practices that promoted accessibility, reproducibility and transparency in research as a means to increase the impact, efficiency and uptake of academic knowledge and greater return on funding investment.

While these ideas were key to understand what Open Science was about, they only provided a partial picture. The universal definition of Open Science did not tell us enough about the different material, cultural and social conditions in which science was practiced in diverse contexts by different actors around the world. We also recognized that one of the main reasons for their popularity was rooted in the systemic biases in academic knowledge production, which afforded much more visibility to research practices and knowledge produced in the Global North, compared to how much we know about knowledge produced in the rest of the world (CZERNIEWICZ, 2013). The result being that a set of key voices and interests have been missing from the global conversation. 
IRIS

In response to this, OCSDNet was very intentional about focusing the study towards understanding what was missing from this discourse, approaching Open Science from a Global South perspective. To do this, the research team created a network with twelve research teams based in Latin America, Africa, the Middle East and Asia, each investigating how Open Science was defined and practiced in their local and regional context, and in what ways it was impacting the sustainable development of their communities (Figure 1).

Figure 1. Distribution of OCSDNet 12 research teams

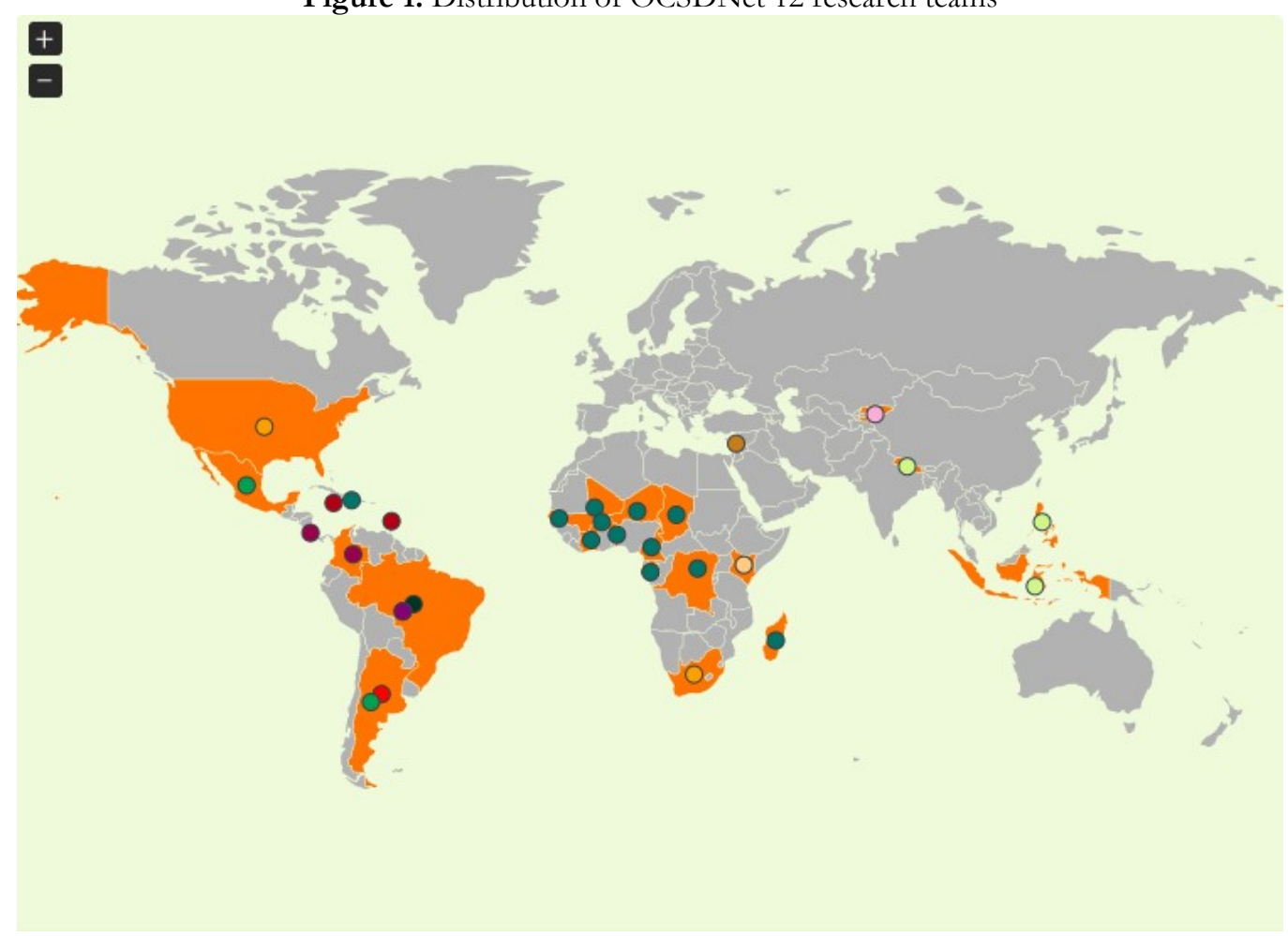

Source: The authors

Each research team approached Open Science from a different perspective. While some studied how open science practices impacted research culture at universities or local policy making, most teams worked to understand how it manifested at the grassroots level by partnering up and conducting research with social movement activists, school children and women in rural areas, indigenous communities and open software and hardware practitioners, among others - (all of these groups are usually referred to as the "general public" or "citizens" in Open Science policies, even though there is tremendous diversity within and between projects).

Emerging findings from the research teams started telling a very different story. As teams investigated the notions, perceptions and applications of Open Science in their 
IRIS

particular regions they found that, across the network, there were set of political, economic, social and cultural systemic barriers affecting the ability of each community to share their stories, perspectives and knowledge with decision makers. Often times, these were the very same barriers preventing these groups from actively defining their development agenda and participating in decision making processes, suggesting an intrinsic relationship between knowledge making and community-led development.

In order to communicate this finding and introduce this narrative into discussions about Open Science, OCSDNet produced the 'Open and Collaborative Science Manifesto', a document that draws from the diverse worldviews and challenges of the communities who were part of the network to propose seven value propositions which ought to be at the foundation of a more inclusive and equitable practice of Open Science. These values underlie a series of interrelated actions:

1. To enable a knowledge commons;

2. To integrate diverse scientific traditions and ways of knowing into scientific production;

3. To address the role of power and inequality in knowledge production and sharing;

4. To create opportunities for participation at all stages of the research process;

5. To foster equitable collaboration between scientists and social figures;

6. To incentivize the design of inclusive infrastructures;

7. To improve the social and environmental well-being of our society and planet.

The Manifesto calls for reflection upon the ways in which Open Science may be reproducing global inequalities in scientific research and development processes and recognizes that there is not one right way to do open science - that the knowledge production process requires constant negotiation and reflection, and the process will always differ by context.

\section{Are these values present in Open Science policies?}

By the time the Manifesto was published in 2017, 'Open Science' had already become a popular public policy object, with Open science policies and programs being produced by global stakeholders, including the UNESCO (2017), the G7 (2017) and the OECD (2015). Over 25 Open Science policies were produced by European stakeholders, including the 
European Commission who adopted it as an umbrella term for EU-wide research and innovation programmes. In North America, Open Science was referenced in reports and policies by the governments of United States and Canada; in Asia, the Japanese Ministry of Education, Culture, Sports, and Technology produced white papers and expert panel reports; in Latin America, Colombia, Mexico, and Chile released their own national policies and the Latin-American repository network 'La Referencia' (consisting of Argentina, Brazil, Chile, Colombia, Ecuador, México, Perú, Venezuela, and El Salvador) produced a document on open science infrastructures.

A recent study conducted by the Knowledge GAP collective (ALBORNOZ et al, 2018), looked comparatively at the narratives stemming from policies from all around the world, and found that they are collectively producing and replicating a discourse that predominantly frames Open Science as:

- A practice that focuses on making research available "with no or minimal restriction" (OECD, 2015) using a language that promotes openness "everywhere and for everyone". Open Science is described as a practice that seeks to maximize research outputs and increase their value at all stages of the research process (DAKAR DECLARATION ON OPEN SCIENCE IN AFRICA, 2017).

- Facilitates and drives of socio-economic growth, or in the case of Europe, also "strengthens the global competitiveness of European research" (LIBER STATEMENT ON ENABLING OPEN SCIENCE, 2014, MALLORCA OPEN SCIENCE, 2017). This was also evident in use of market-based language to describe how Open Science improves efficiency, reduces costs, and ensures a "return on investment" for research, data storage search, and diffusion.

- A means to achieve an innovation-based economy (MALLORCA OPEN SCIENCE, 2017). Policies supported the investment in tools, technologies and infrastructures that facilitated "knowledge and data exploitation" (PROMOTING OPEN SCIENCE IN JAPAN, 2015) and data-driven innovation (LIBER STATEMENT ON ENABLING OPEN SCIENCE, 2014).

- A practice dependent on the development of research infrastructures, data scientists and technical experts, who need to develop competencies in open data skills, data management skills, and the use of infrastructure, analytics technologies, and more 


\section{IRIS}

(MALLORCA OPEN SCIENCE, 2017, EU SCIENCE WITH AND FOR SOCIETY WORK PROGRAMME 2018-2020, REPORT ON THE FORUM ON

OPEN DATA AND OPEN SCIENCE IN AGRICULTURE KENYA, 2015; PROMOTING OPEN SCIENCE IN JAPAN, 2015).

This language's focus on technology-led productivity, efficiency and competition is a stark departure from the values identified as essential for an equitable Open Science in the OCSDNet Manifesto. More importantly, it raises red flags in terms of who is really being represented by these policies and who will be able to enjoy its benefits. We must ask: what assumptions are embedded in narratives about Open Science, whose interests are they serving and in turn whose interests are neglected in this framing?

Asking these questions is also a matter of cognitive or epistemic justice - the idea put forth by the scholar Boaventura de Santos Sousa that questions whose ideas and visions have the power and legitimacy to shape future possibilities. The ideas that prevail in policy-making processes have the power to influence how resources are channeled, what programs are implemented, and the meanings we attribute to issues of public interest. It is important to question them, especially when narratives are emerging from actors who hold political and economic power.

In this light, and to contribute towards a discussion that critically evaluates Open Science policies from the perspective of grassroots communities, OCSDNet offers three alternative ways to think about Open Science:

\section{Open Science as a historically produced discourse}

To see open science as a historically produced discourse means abandoning the notion that openness is always inherently positive and/or neutral and considering how meanings of openness are embedded in particular historical legacies, contexts and sociopolitical struggles (TRAYNOR and FOSTER, 2017; CHRISTEN, 2012)

This was evident in the experience of the research team working in South Africa to coproduce research ethic contracts with local indigenous researchers. The research team found that within several indigenous communities there was strong resistance to the idea of openness, as a result of the ways in which indigenous knowledge had been historically misused, appropriated or exploited in the name of colonialism and neoliberalism in the past. 


\section{IRIS}

One of the research teams working in Argentina initially focused on promoting openness among social movements and activists advocating for environmental sustainability. The scientists conducting the research assumed that the open sharing of knowledge could bring about more cohesive advocacy and mobilization between activists. However they found that activists were not willing to share key information and strategies openly out of fear of persecution by the state, the industry or other academics.

For both teams, de-contextualizing openness from its history and political contexts meant erasing the experiences of vulnerable communities who had been or continue to be harmed by it and ignoring how openness could sustain power structures built on cognitive and material exploitation and power abuse. Borrowing from feminist critique of science, OCSDNet proposes the concept of: situated openness - a definition of openness that recognizes the context, history and power structures in which it operates (TRAYNOR; FOSTER, 2017), and that constantly interrogates whose histories and whose interests it is serving.

\section{Open Science as a sociopolitical process}

Those practicing and promoting Open Science need to be aware of the social and political dimensions of knowledge and technology. We must recognize that Open Science operates within the super structures of global capitalism, a model that has historically benefitted those with greater access to wealth and resources, than those in a more vulnerable position. We learned this from two research teams that were working closely with tools and technologies that promote Open Science and found that developing inclusive and equitable social infrastructures for Open Science was as, if not more important, than developing technical infrastructures.

The research team working in Indonesia, Thailand and Nepal, promoted the use of low-cost technologies as a means to democratize science and art among non-expert communities. Through citizen science and open hardware workshops, this team found that within the community, openness was thought of as an everyday practice of knowledge sharing and community-building. The technologies used in these processes facilitated but did not define the processes of learning, social bonding and sharing that took place among them.

Similarly, in Brazil, the team building a virtual open biodiversity data repository, found that the repository was most effective when the users had an opportunity to interact and provide their input to the designers of the repository. One of their main conclusions was that 
in Open Science, it is imperative to nurture the human and social networks surrounding infrastructures; letting the social drive the technology, rather than technology drive the social.

Both of these cases contrast with the discourse present in Open Science policies that subordinates the social value of knowledge to its economic value and frames science as a tool to enhance market productivity and competition. Disregarding social inequality and inequitable distribution of opportunities in the equation, limits our ability to think about how to foster meaningful public participation in these processes. When we approach Open Science, we must ask - to what extent does Open Science only benefit those who are already in power and in what ways does it marginalize community-based science? We must address how open science continues to operate within a system of global academic knowledge production that remains unequal and uneven, prone to benefit wealthier researchers and institutions around the world, neglecting the role of community-based science.

\section{Open Science as mechanism to redress systemic biases and inequalities}

Finally, OCSDNet found that an Open Science that recognizes the value of community-based forms of knowledge production can create spaces of political and social change, in which actors that have face systemic discrimination or exclusion can participate more actively in processes of formal and informal knowledge production.

For example, the research team based in Colombia and Costa Rica, working with coffee-plantation farmers driving agroecology programs in their regions, found that reclaiming and reframing Open Science was key to develop local ownership over its practice. Colombian farmers proposed a notion of openness that involved meaningful collaboration between actors who had both traditional knowledges and scientific knowledge about agriculture and shared the Andean development philosophy of Buen Vivir or Living Well. The objective was not to make science more efficient, but to ensure social and environmental well-being was at the core of the knowledge production process .

In the case of the team based in Lebanon, the research team developed low-cost and DIY technologies and methods to measure water contamination in rural areas, with the objective of making environmental stewardship more accessible for local communities. Unexpectedly, it was women who expressed the most interest in developing these skills, leveraging the practice of Open Science as a means to position themselves as advocates for their communities and stewards of collective resources. 
IRIS)

To redress systemic injustice involves questioning who is being left out of the Open Science agenda. Practices of openness have the potential of disrupting the status quo when they question who gets to lead and participate in processes of knowledge production and sharing, and who gets to decide how this knowledge is applied. In doing so we are interrogating power, inequality and the barriers that prevent actors from having an influence over decisions that affect them. But more importantly, we are exercising self-reflection recognizing that how the gaps in the Open Science discourse can only be filled by the very same groups which are often excluded from the process of defining what it means.

\section{Final notes: Can Open Science transform science?}

As put forth by the development scholar John Gaventa, transformation involves a "paradigmatic shift in how we see the world and in how we understand and measure progress" (GAVENTA, 2015). It may still be too early to accurately assess whether Open Science will lead to a paradigmatic shift in how we measure the value and impact of scientific production. However, as open science advocates we must ask ourselves: how can we contribute towards this goal? And where could we draw alternatives from? The examples provided in this short piece are meant to serve as a reminder of how diverse worldviews and experiences can help us stay critical of hegemonic narratives that emerge about Open Science. In particular, we need to critically question those narratives that normalize norms and ways of thinking that reproduce global inequality and disregard the political nature of knowledge and science. Learning and collaborating with grassroots communities, civil society and vulnerable and historically marginalized groups is one of the key radical actions we can take to work towards cognitive justice; affording their experiences and stories the same attention and legitimacy we give western science and public policies that support them.

\section{References}

ALBORNOZ, D. et al. Framing Power: Tracing Key Discourses in Open Science Policies. ELPUB Jun. 2018.

CHRISTEN, K. Does Information Really Want to be Free? Indigenous Knowledge Systems and the Question of Openness. International Journal Of Communication, v. 6, n. 24, 2012. Disponível em: <http://ijoc.org/index.php/ijoc/article/view/1618>. Acesso em: 03 set. 2018. 
IRIS)

CZERNIEWICZ, L. Inequitable power dynamics of global knowledge production and exchange must be confronted head on. LSE Impact Blog. 2013. Disponível em:

$<$ http://blogs.lse.ac.uk/impactofsocialsciences/2013/04/29/redrawing-the-map-from-access-toparticipation/>. Acesso em: 03 set. 2018.

DAKAR DECLARATION ON OPEN SCIENCE IN AFRICA. Sci-GaIA Consortium. 2016. Disponível em: <http://www.sci-gaia.eu/dakar-declaration/>. Acesso em: 03 set. 2018.

EU SCIENCE WITH AND FOR SOCIETY WORK PROGRAMME 2018-2020. European

Commission 2017. Disponível em: < https://bit.ly/1GinND9>. Acesso em: 03 set. 2018.

FORUM ON OPEN DATA AND OPEN SCIENCE IN AGRICULTURE. Agricultural Information Management Standards (AIMS). Kenya, 2015. Disponível em: <https://bit.ly/2KzLLxn>. Acesso em: 03 set. 2018.

GAVENTA, J. From Development to Transformation: Citizen Engagement for Social and Cognitive Justice. In: CASAE/CASID Conference, University of Victoria, Jun, 2013. Disponível em: $<$ https://www.casid-acedi.ca/gaventa-from-development-to-transformation>. Acesso em: 03 set. 2018.

LIBER. LIBER Statement on Enabling Open Science. 2014. Disponível em: <https://bit.ly/2neK6UC>. Acesso em: 03 set. 2018.

MALLORCA DECLARATION ON OPEN SCIENCE. European Commission. 2017. Disponível em: <https://bit.ly/2M1V65R>. Acesso em: 03 set. 2018.

OECD. Making Open Science a Reality. Paris: OECD Science, Technology and Industry Policy Papers, 2015. Disponível em: <https://bit.ly/2vDPR1Q>. Acesso em: 03 set. 2018.

PROMOTING OPEN SCIENCE IN JAPAN. The Expert Panel on Open Science, based on Global Perspectives. Cabinet office, Government of Japan, 2015. Disponível em: <https://bit.ly/2vKdiGK>. Acesso em: 03 set. 2018.

TRAYNOR, C.; FOSTER, L. Principles and practice in open science: Addressing power and inequality through "situated openness". Natural Justice. 2017. Disponível em:

<https://bit.ly/2z9fV5W>. Acesso em: 03 set. 2018.

Data de submissão: 07-08-2018

Data de aceitação: 03-09-2018 